\title{
Waiting for Godot is an Irish Endgame: A Postcolonial Reading of Samuel Beckett's
}

\section{Waiting for Godot and Endgame}

\author{
Sayyed Rahim Moosavinia \\ Faculty of Letters \& Humanities, Shahid Chamran University \\ Ahvaz, Khuzestan, Iran \\ Tel: 0098-916-632-0024 E-mail: moosavinia@scu.ac.ir \\ Bamshad Hekmatshoar Tabari (MA Student) \\ Faculty of Letters \& Humanities, Shahid Chamran University \\ Ahvaz, Khuzestan, Iran \\ Tel: 0098-911-216-1376 E-mail: bami_1367@yahoo.com
}

Received: 25-07- 2012

doi:10.7575/ijalel.v.2n.1p.60
Accepted: 14-09- 2012

Published: 01-01- 2013

URL: http://dx.doi.org/10.7575/ijalel.v.2n.1p.60

\begin{abstract}
Irish National Drama is very sensitive when it comes to the issue of English Colonization, colonial forces, independence and the matter of post-colonial. In fact, a kind of Irish consciousness is present in all the dramas of this nation and all playwrights in this trend- even indirectly or by implication- have tried to portray these matters through their works. This study is an attempt to prove the claim that even a playwright like Samuel Beckett, whose works have been written out of the canon of Irish Literature because of living on exile, adopting another language or semi-taboo labels like Absurdism, Universality and Placlessness, can be read in light postcolinalism. To this aim, two of Beckett's plays Waiting for Godot and End Game are chosen here as the representative and put into explication.
\end{abstract}

Keywords: Irish, postcolonialsim, absurdism, universality, placlessness, colonizer, colonized

\section{Introduction}

It is not much easy to speak about the art of dramaturgy on the island located in the north-west of Europe, where is called Ireland. It has much to offer to a literary study as its history is filled with different racial, cultural, religious and political crises. The analysis of the history of Irish Drama will take the researcher back much in time to the point where he can meet the fusion of Irish - Gaelic as well as Celtic - tribal traditions of performance with that of New Roman arrival based on a new religious pattern. It is interesting to speak about how Christopher Morash (2002), explicates this long history and extracts evidences to prove the precedence of this old trend in drama: He refers to "Neal Moore, the traditional Irish Fool" and "flid", who would compose verses in complex meters", and believes that it dates back to the seventh century, while the manifestation of such artistic techniques of performance could yet be found in the seventeenth century Irish drama, as well as the performance of "liturgical" plays, like Visitatio Sepuleri, which were popular in churches till the age of Renaissance (p.3). The presence of seanchai - as an effective strategy for storytelling as old as medieval spectacles can also be another proof to the matter (Gleitman, 2008,p. 42).

\section{Irish Drama and Postcolonialism}

But besides this rich tradition of drama and performance, there is one more recent phenomenon that has made modern Irish Drama different in nature from any other dramas of the world. That is the way it lends itself to postcolonial studies, or as Richards (2004), asserts," while Ireland had already enjoyed theatre as an art form and entertainment for several centuries, drama in its late nineteenth and early twentieth-century manifestation sought to define and determine the basis of Irish claims for political independence from Britain"( p.17). In fact, national concern plus socio-political conflicts in Ireland's recent century's atmosphere due to the struggles for independence has made for the establishment of a new Irish Theatre, that is "realistic", "text-driven" and "linguistics-based", aiming at the portrayal of "peasant or working-class characters"(p.165), all conscious of "the catastrophic dimension of Irish history, the litany of poverty, war, humiliation"(McDonald,2002,p.2), and the hegemonic forces of the English colonizers.

Of the characteristics that have been mentioned above, realism and text-dependency for the portrayal of meaning, as well as thematic significances, is not only the characteristic of Irish drama's revolutionary spirit and has gained much from nineteenth century European Realistic Drama, but the third feature needs some elaboration as it is significant 
enough to be linked to postcolonialism. Postcolonial critics emphasize much on the matter of language and the way a colonized nation finally reaches a state of consciousness in the case of the adoption of a language for expressing his own version of reality. According to Spivak, "the subaltern cannot speak," ( cited in Pearson,2001, 226), not only because he cannot find a medium to speak through, but because it has been imposed on him that there always exists a cultural or gender difference, a hierarchy between him and the colonizer, something that would shake him to death at the presence of the colonizer. Based on her theory, the linguistic concerns of National Irish Drama can be defined so: from the twelfth century onward, the presence of English colonizers in Ireland ruined the linguistic autonomy of this nation and brought many restriction to the application of Gaelic Language - that was old and rich in reference - in social, cultural and political affairs. So Irish people were repressed and the legitimacy and grandeur of their language was in threat and an "english" (Ashcroft, Griffiths, \& Tiffin, 2002, p.7), was imposed upon them, which would do nothing, but stereotyping them, making them like strangers or the "other", in Spivak's term (cited in Ashcroft , Griffiths , \& Tiffin, 1995, p. 24). Now it is clear that why one of the major concerns of National Irish Drama was solving the issue of language. Yeats' attempts to find a solution seem to be most effective: not necessarily using Gaelic or ignoring the authenticity of English, but looking for lingual artifacts that would revitalize the old Irish heritage and blow a new breath to the struggles not for a physical combat, but for the "decolonization of minds" at the first instance - as it is portrayed by implication in his poem "Easter 1916" (Hyland \& Sammells, 1994, p.144):
Too long a sacrifice
Can make a stone of the heart.
$\mathrm{O}$ when may it suffice?
That is heaven's part, our part
To murmur name upon name,
As a mother names her child
When sleep at last has come
On limbs that had run wild.
What is it but nightfall?
No, no, not night but death.
Was it needless death after all?
For England may keep faith
For all that is done and said.

Many critics agree with each other in introducing Synge and O'Casey besides Yeats, as the heralds of Irish National Theatre - much successful in energizing the process of decolonization by the assistance of the techniques and strategies that were " the handmaid of Irish nationalism" (Richards, 2004,p. 2). But there is usually much ambiguity in the issue when this movement at its early life coincides with the first decades of Free Irish State - with all its struggles for revival through numerous crises - and sees on waves the catastrophe of the Great Repression of the 1930's and the Second World War. The best thing to do at this point in order to trace the metamorphosis that came to the national concerns of Irish drama at this period - or the postcolonial zone - is to focus on a figure like Samuel Beckett whose works seem to be the best representatives of the spirit of the age.

\section{Samuel Beckett}

Samuel Beckett, the Irish playwright who had been living much of his life in Paris - writing in French - is usually written out of the Irish canon of literature. Yet it is ironic that his influence on the Irish drama of the twentieth century has been so much that he is even sometimes titled "the ghostly founding father of Irish theatre" (McDonald, 2002, p.157), from the half century onward. The source of influence seems to be his specific worldview, the way it was challenged, and the way it affected his style of writing as it underwent a metamorphosis to match the demands of the age in which he was living. In fact, on a micro level he is the Irish man and his works reflect the way the world is changing for men of that nation. So an explication of the life and works of Samuel Beckett can assist much in tracing the process of development and maturation of Irish National Drama and the way it can be related to postcolonial studies.

Samuel Beckett was born in Dublin in 1906, the son of a quantity surveyor. As a child he spent a happy life in a country house and went to Trinity College in 1923 where he studied French and Italian, receiving his B.A degree in 1927. In 1928, he went to Paris where he started teaching at Ecole Normale. This was the beginning of his life-long attachment with Paris as he finally comes to choose Paris his new home and French the Language of his writings. He obtains his Master of Art at the age of twenty four from London with an essay concerned with the interpretation of Proust's works. During the war years he and Suzanne, his French wife, face many disasters and live a life of catastrophe. When the war ends, he starts writing plays in French that bring much fame and honor to him. He wins Noble Prize for Literature because of his plays in 1969 and dies in 1989.

The former paragraph may provide a brief biography of Samuel Beckett and give a brief review of him, but to probe the relation that exists between him and Irish National theatre and his influence on it, one must go deeper and focus on his life as a dramatist. Beckett's life as a man of drama can be divided into two periods: the Pre-War and the Post-War Period. Each period would be elaborated respectively: 


\subsection{Beckett's Pre-War Period}

The Pre-War Period is marked by English. This coincides with his early life at Dublin and the way he would look at the world from that prospect. According to Esslin (2001), Beckett's "Anglo-Irish origin" that is being born in a "Protestant Irish Middle Class Family" justifies his "preoccupation with the problem of being and self-identity" (p.29). In other words, the feeling of being one from the religious minority and the descendant of the colonizers in a country that is suffering from the hallmarks of colonization may bring many doubts to an educated young man finding himself a part of a whole that is apart. It is under such a circumstance that Beckett finds it necessary to establish a stable worldview, a way of looking at the world that matches his living reality and would not flatter him. In quest of such stability, he confronts many crises: sometimes he comes to rely on his childhood visions about playing with stones at the beach and his love for minerals, and would relate it to Freud's view "that human beings have a pre-birth nostalgia to return to the mineral state"(Knowlson,2004,p. 46) sometimes much dazzled, he would go to Democritus and his view that "nothing is more real than nothing" ( Knowlson,2004,p.320), and many times he would stop thinking about his identity and the world when he would remember his numb feeling of facing the currents of Irish Free Sate, Northern Ireland, and the disintegration of his country at his early days in Trinity College.

To be precise, in order to look for the dominant ideology in Beckett's Pre-War writings, one should go to James Joyce and what fruits his acquaintance with him had for Beckett at the age of twenty three in Paris (Esslin, 2001, p. 30). Under the direct influence of Joyce, Beckett somehow becomes able to come up with his uncertainties about his self-identity, the source of knowledge and the reality of the Irish life and colonialization. His works written at this time are then a criticism of what was happening in Ireland with a language that bears a kind of pessimism, bitterness, irony and direct references to the Dublin life, as well as the Irish countries and landscapes. On the thematic level these plays also aim at the portrayal of the mind of the puzzled Irish man in search of meaning in that specific social, economic and political atmosphere. The best example can be All That Fall, that reflects the way Irish people revenge the postcolonial condition in which they live by a "sardonic and dismissive distaste"(Grene, 2004, p. 319). In commemorating Joyce and defining his debt to him in writing plays like All That Fall, Beckett says:

I realised that Joyce had gone as far as one could in the direction

of knowing more, being in control of one's material. He was always

adding to it; you only have to look at his proofs to see that. I realised

that my own way was in impoverishment, in lack of knowledge and

in talking away, in subtracting rather than adding" (Knowlson,2004,p. 319).

\subsection{Beckett's Post-War Period}

The Post-War Period in Samuel Beckett's writing which is associated with French language can also be called the Phase of French Philosophy or Post-structural Phase, in which he gets much far from his early career marked by the presence of Joyce's ideology. To talk about the causes of this transition several issues shall be probed: the occurrence of the Second World War, Existential Philosophy, and consequently lingual conflicts in Beckett's artistic career.

When the Second World War befell, for another time Europe was in a nightmare and the bitter memory of the previous war darkened the minds. As an Irish expatriate living in France, Beckett was in a perfect place from which to observe the height of German colonial power - comparing it with England's hegemonic presence in Ireland for centuries - as Hitler invaded one country after another. This was for him a meditation on the nature of injustice and violence that finally led him to develop anti-Nazis feelings by becoming an active member of a "Resistance Cell" (Knowlson, 2004, p. 278), in Paris whose job was "secretarial work", translating secret letters or documents into French (Knowlson, 2004, p. 282). In result of such activities he was finally forced to flee from Paris when it was taken by Nazis in 1940.This was the beginning of his disasters as he and Suzanne were always in fear of Gestapo, wandering hungry from one place to another in hope of a shelter. All that happened to Beckett during the war years acted as a stimulus and revealed him "the concrete reality of writing"(Knowlson, 2004, p. 344): something not only in contrast with his former ideology, but also different in nature. He abandoned the Joycean certainty and came to focus on the "poverty, failure, exile and loss", in a world the inhabitant of which was no more anything but a non-knower and a non-can-er"( Knowlson, 2004,p. 320). One may soon find the relation between such transition in Beckett's worldview and the emergence of Existential Philosophy in France.

The Post-War French is marked by the emergence of the Existential Philosophy. It is the time when outstanding figures like Jean Paul Sartre and Albert Camus try to find a solution for the exigency that was threatening the basis of humanity: the catastrophe of the death of humanity or even death of God, as Nietzsche once had uttered. In fact the War had brought such devastation to everything that no one - whether ordinary or intellectual - could be certain about anything by losing his ability to judge. So it will not be surprising to hear Beckett declaring: "All my senses are trained full on me. Dark and silent and stale, I am no prey for them" (Uhlmann, 1999, p.91). Therefore, what may come to that certainty and solidity once present in his works; something that would always be in quest of the outside reality? Or after all, could Beckett keep his attentions from his internal senses calling him to revolt? These questions can be answered by relying on Knowlson (2004):

He would draw henceforward on his own inner world, for his subject outside

reality would be refracted through the filter of his own imagination; inner 
desires and needs would be allowed a much greater freedom of expression;

rational contradictions would be allowed in, and the imagination would be

allowed to create alternative worlds of those conventional reality (pp.319-320).

It seems that the most important thing mentioned in the above quotation is the matter of Subjectivity that can be read in relation to Existential Philosophy. In fact, in this phase Samuel Beckett becomes conscious of the notion of Subjectivity with all its philosophical complexity and the ethics of judgment after the crisis of the Second World War; what brought philosophers like Sartre into new realms in books like Being and Nothingness (Uhlmann, 1999, pp. 9192). To be precise, Beckett has been aware of such a conflict between knowledge and the way the internal world of one demands a source of power to judge when facing the chaos of the outside reality. He was then for the first time able to relate his Irish background marked with colonialism to the present, in a struggle to give birth to a new form of writing which would bridge the gap between the subjective and the objective ; what Deleuze and Guattari mention in What is Philosophy?, about form: "the artist can make an artistic form, only through his ability to respond to that chaos which shall be processed by the filter of his mind by the very act of Subjectification" (cited in Uhlmann, 1999,pp. 93). To sum up what has been mentioned till this point, it can be said that Beckett came finally to the understanding of such a process and was able to adapt himself with the philosophy of the new age - which was giving literature of the age Philosophical and Post-structural dimensions without ignoring his background, the demanding of his nation, and their aims even in an indirect way. It seems then a sheer compliment when in one of his last interviews he declares: "What is Existentialism? Tell me! I have never thought of that in my work. I am not a Philosopher" (Kamyabi Mesak, 2002, p.10).

The last element to talk about, in relation to the characteristics of Beckett's second phase of writing and its relation to postcolonialism is the matter of Lingual Conflicts. In fact, the impact of War and the emergence of New Philosophies brought Beckett to a point where he found it necessary to revise his format of writing. The first thing that was done by him was the adoption of French as the language of his writings. This can be said to have two reasons: first to detach himself from James Joyce, as he felt yet the traces of Joyce's hegemonic presence on his English writings that had in his own terms somehow colonized him, the same as the English colonizers colonizing Ireland. In fact by that, he intended to escape from the "erudite and literary allusions and what he called 'Anglo-Irish Exuberance and automatism' "(Knowlson, 2004, p. 324). Another reason can be his belief in the fact that French would aid him in reaching that kind of objectivity just mentioned above by creating a "linguistic oddity" in result of "deviating French syntax or phraseology" (Knowlson, 2004, p. 327). According to McDonald this is the very strategy that assists Beckett in giving his works a sense of universality, placelessness, or better to say an "Imaginative Geography" (2002, p. 140).

Besides that linguistic transition in Beckett, one may find other manifestations of the lingual metamorphosis in him when relates it with what Esslin introduces as Absurdity in Post-War Theatre. According to Esslin (2002), the spirit of the age and the dominance of "Existential philosophy" paved the ground for the emergence of a kind of nothingness or Absurdity in works of Beckett that is portrayed in his plays on the lingual, thematic and performance levels (p.24). What concerns this study at this point is the linguistic Absurdity of Beckett's plays. This kind of Absurdity may be characterized by "the indeterminacy of language, and employs techniques of babbling, failed efforts of communication, repetition, and untidy proliferation to create tension between meaning and nonmeaning"(Hodges, 2010, p. 21).The most important thing to be mentioned at this point is the fact that the Absurdity present in Beckett's works is just a device in service of his struggle to grasp the desired effects and form in his Post-War Period of writing and is not put there for its own sake as Esslin have claimed.

\section{Postcolonial Reading of Beckett's Waiting for Godot and Endgame}

Now that the major characteristics of the Beckett's second phase of writing have been discussed fully, it seems now quite proper to focus on the main subject of this study that is the Postcolonial Reading of Beckett's Waiting for Godot and Endgame, as they belong to this phase. What has been done till this point from the elaboration of the history of National Irish Theatre to Beckett's biography and artistic career was an struggle to determine the historical context in which these works have been produced as Fredrick Jameson has emphasized on historicizing the texts under analysis. This act of historicizing is of much significance in a postcolonial study of Becket for some reasons: first of all because the colonizer-colonized relation which is one of the important issues to be investigated is something real and not of imaginary existence and shall not be considered as things that have happened in void. So to apply postcolonial approaches to these two plays of Beckett, what has been done, seems necessary. Besides, knowing about the life or biography of a writer is very important in postcolonial studies, as these studies aim at the explication of the texts for extracting those elements that can shed light on Power Relations - as Foucault believes -hidden in the deeper layer of the texts. This can be done only when the investigator knows enough about the writer, his life and the way the present power sources in it have influenced his writing: what may speak instead of the silences in the text (Brandabur, 2006).

\subsection{Waiting for Godot}

En attendant Godot or Waiting for Godot, which went on stage on 5, January 1953 at the Thèâtre du Babylone in Paris, is Beckett's "real triumph"(Esslin, 2002, p.39). It soon came to be known as one great success of the Post-War Theatre and was translated into more than twenty languages. But what are those elements that make for such an excellence in Post-War drama of Europe? For sure, it cannot be just related to the plot of the play or being categorized later under the title of an Absurd play by Esslin: Two tramps named Vladimir and Estragon staying together in a desert-like area handling nonsense or absurd dialogues to kill time while they are waiting for a man named Godot to come. In fact, it is 
the existential connotations of the play and many references to the religious notion of waiting for a "savior", (Ghanbari,2008,p.735 ) - reinforced by the apocalyptic setting of the play- that gives it much more significance in the eyes of the war-worn European audience. The European is tired of the cruel world and is aimlessly looking for something that may soothe him for a while. He knows that it is promised by the Holy Scriptures, but he can no more be certain about anything and the inaction coming to him in such a situation has provided him an inevitable absurdity, taking him nowhere.

What has been mentioned above is what one may read in an analysis of Waiting for Godot; what is done in light of Esslin's guidelines in The Theatre of Absurd. But as it was discussed in the previous parts, in order to investigate the significance of this play from a postcolonial perspective, one should try to place it exactly in its historical context. It may be somehow hard to do so, because of the indirectness of a play of Beckett from the second phase and the way it conceals its references from the outside world in result of the fusion of subjective and objective. Therefore, it is good to start the analysis by putting Vladimir and Estragon and the notion of waiting in center and view them from the postcolonial prospect. According to Knowlson (2004), even though Vladimir and Estragon are cosmopolitan characters and represent man's condition in Post-War years, in the first instance they stand for Samuel and Suzzane themselves when on their way south in fear of Gestapo had the same tramp-like life: "sleeping in ditches, waiting by the road side and eating scraps from chicken bones" hoping for a rescue to come (p.343). In fact, it was such a condition that opened Beckett's eyes to the reality of writing (p.344), as he became able to express the boring experience of waiting and silences of his tramp-days by words; words that besides their haphazard appearance or the absurd reflection of men's situation would speak for what goes on inside figures like Vladimir and Estragon and the way their dazzled mind long for making sense of the reality of waiting hopelessly. This kind of helplessness and bamboozlement is so great that even they sometimes forget about everything and their purpose for waiting becomes so blurred in their mind that it turns into a routine habit. This fact is portrayed in Waiting for Godot by the frequency of the words or phrases that are related to the notion of waiting and much reoccurrence of dialogues like what follows:

ESTRAGON : Let's go

VLADIMIR : We can't.

ESTRAGON : Why not?

VLADIMIR : We're waiting for Godot ( Act I: 15).

Besides what was discussed above, there is one more issue related to the matter of waiting that can be very significant in a postcolonial study and that is the ideological aspects of waiting. This can be analyzed by relying on the notion of ideology in Marxism and the way a postcolonial reading can make use of it. The colonizer does whatever he can to control the colonized - he may use military forces, political strategies or ideological devices. The notion of ideology seems to be much related to this discussion. If the philosophy of waiting is considered to be something not real and only an ideological device in the hand of Godot or any other source of power not known to the audience, it can be concluded that Vladimir and Estragon are the examples of people in a colonized society who are kept away from searching for reality and taking due actions to reach the necessary class consciousness. In other words, through the interpolation of the ideology of waiting, they fall in a kind of numbness that they do not feel the trauma they suffer from and go on in hope of a savior in lack of the required insights.

To trace other clues related to a postcolonial study of Waiting for Godot, the relation between Lucky and Pozzo shall be put into analysis here. Esslin (2002) believes that "Pozzo is a sadistic master and Lucky a submissive slave"(p.46) to him, who carries not only his luggage, but also the whip with which Pozzo beats him. In fact, Pozzo's dominance on Lucky is to so great that, he even orders him when to think. If Pozzo is taken as "a greedy landlord", Lucky is the example of an exploited peasant and if Pozzo the representative of "capital and corporate power", Lucky can be considered as "a failed scholar, philosopher, and poet" whose muteness in much of the play and his sudden outburst of schizophrenic sentences at Pozzo's order to think, stands for the way the colonizer may repress the colonized ( Brandabur, 2006,p.123). Or as Lyon puts in words in another way, Pozzo's attitude toward Lucky which can be said to be the nonverbal language of the colonizer, "isolates Lucky as an image of a disfranchised intellectual who functions as a type of licensed fool"(cited in Hyland \& Sammells,1994, pp.193-194). This becomes much more vivid when the audience is informed from Pozzo's words that he is going to sell Lucky at a fair even though much of what he knows has been once taught to him by Lucky. Pozzo's attitude toward Estragon and Vladimir in the first act also reflects the authority of such a kind in him, as it is very clear at the point where Estragon voraciously begs for the bones and the leftovers of the chicken that Pozzo was eating. The wine which Pozzo drinks at that moment and the way he responds to Estragon's request, his pipe and his manner of talking also portray a negative picture of him: a cruel colonizer or landlord who has been living for long in prosperity and comfort in result of the exploitation of others.

It is also significant to talk about the matter of Pozzo's blindness and Lucky's muteness. In the first act Pozzo wears a pair of glasses and he possesses a watch that he has inherited from his grandfather. That can be the symbol of time and consequently the colonizer's dominance through ages. He is also too strong and can justify his attitude toward Lucky for Vladimir and Estragon as he talks in a way that shows his knowledge of the environment - he is the owner of that land and knows everything about it: the sunset, time and history. But in the second act he appears as a blind man on the stage. He cannot keep his balance while being guided by Lucky, and when he falls he even begs for Estragon and Vladimir's help with many lamentations. He cannot remember Estragon and Vladimir, whom he had met the day before. He has lost his sense of time and cannot tell, for how much time he is on that way. What gives more 
significance to these elements is the fact that Lucky has become dumb in this act. Actually, Beckett intends to represent the diminishing authority of Pozzo and the way his lack of insight can stand for the narrow- minded dictator, colonizer or exploiter. This can be expanded by relying on postcolonial theories of Homi Bhabha (1990): the colonizer is always blind to what he is doing to the colonized, as he is not aware of the ambivalence that may exist in their relation and the way the colonized would adopt the new language of resistance. The colonizer thinks he can keep his dominance on the colonized, but he will soon find the impossibility of that. This can be traced in the second act of the play as Vladimir and Estragon ask for money facing Pozzo and his begging for help and Lucky's muteness and inaction during the whole act.

By what has been discussed till this point, it can be concluded that Samuel Beckett's Waiting for Godot, besides all other readings can be read in light of the postcolonial approach. In order to do so, a series of issues with the centrality of two notions of Waiting and colonizer-colonized relation were studied. At this point it can be claimed that this play of Beckett on the whole is a reflection of the structure of world powers' dominance over the community of people and the way they control them through different strategies, the way their relation is shaped and finally what comes off this ambivalent relation at the end.

\subsection{Endgame}

After focusing on Waiting for Godot, the turn goes to Fin de Partie or Endgame that is another masterpiece by Beckett written in 1967. Like Waiting for Godot, Endgame can be read based on postcolonial theories because of the existing similarities and connections on different levels. Beckett himself once declares: "You must realize that Hamm and Clov are Didi and Gogo [Stragon and Vladmir] at a later date, at the end of their lives. Actually they are Suzanne and me" (Brandabur, 2006, p.129). What elements do these two plays have in common that make Beckett speak thus? The answer seems to be found by performing an analysis of the relation between Hamm and Clov- the two major characters of the play - and the way they can be studied according to the postcolonial approach.

The relation between Hamm and Clov represents that of a master and slave. According to Pearson (2001), the relationship between Hamm and Clov is that of the "co-dependency between two leftover participants from an imperialcolonial historical situation that no longer exists"(p.216), the co-dependency that according to the Hegelian master-slave dialectics would make for the formation of the consciousness of the two poles and their ideology: the ideology or worldview of the thesis that is master and the anti-thesis which is the slave. But what is the reason for the codependency between Ham and Clov that reflects no more a dialectics or better to say a synthesis? Maybe the following quotation is the best response:

HAMM: Gone from me you'd be dead.

\section{CLOV: And vice versa.}

\section{HAMM: Outside of here it's death! (Endgame 126)}

In fact, this master and slave are kept together as there is no other one left and they are the last two inhabitants of the world. Beckett's belief that they represent Estragon and Vladmir at the end of their lives can also be interpreted in light of the above issue: after living a life of uncertainty that is associated with waiting in different senses, Estragon and Vladimir- or Hamm and Clov-would meet their death at the isolated world of their own, built on the basis of an ideology - a world in which everything is going to be finished. That is why, Endgame begins so: "Finished. It's finished, nearly finished, it must be nearly finished".

Besides what was mentioned above, it can be claimed that the relation between Hamm and Clov can be considered parallel to the relation between Pozzo and Lucky. Like Pozzo, the authority is in hand of Hamm and he possesses the lard which Clov is eager to know its content - that may stand for what the poor colonized may feel about the belongings of the colonizer as the source of his superiority and hegemony. Yet there is some other clues in the text of the play that sheds light on Hamm's background as a powerful colonizer: the way he talks about Clov's father and his arrival there to ask for some corn for his child that standing for Hamm's "authority of socio-economic status" (Hyland \& Sammells, 1994, pp.192-193) at that time, his attitude toward Nell and Nagg, and his refusal to give oil to mother Pegg for her lamp who finally dies of darkness.

Additionally, there is another similarity between Hamm and Pozzo that is blindness. As a colonizer - though diminished in authority - Hamm always takes charge of everything and this is portrayed in the play by sitting on a chair in the center of the scene. He controls Clov's understanding of what goes outside when he explores with a telescope outside the window (Pearson, 2001), and tells the story of Clov's arrival there to him as a child over and over. That can stand for the way the colonizer would manipulate reality - something which the colonized may have no memory of - and produces his own version of it to control the colonized ideologically. By taking all of these issues into consideration it becomes clear how ironic Hamm's blindness and his taking pills to take its pains away may be.

Clov has also the same condition as Lucky. He is bound to his master and is repressed in different aspects. The most significant issue to talk about in this case is the matter of Clov's identity, his language and Hamm's presence as the figure of authority in affecting them and how they can be related to postcolonial issues. The only clue from the text of the play that can help the investigator to probe the issue of Clov's identity is the story of the arrival of Clov's father and asking Hamm to adopt Clov as his son. Pearson here refers to the fact that during one of his narrations, Hamm mentions "Cobh", as the exact geographical place that Clov's father had come from. He then tries to relate this to the due historical context to give a postcolonial reading of it: "During British occupation, Spike Island, which lies in the harbor 
at Cobh, was a British military post where Irish political prisoners were kept and later trans-ported to Botany Bay, a British penal colony in Australia"( Pearson, 2001,p.222). And he concludes that Beckett has artistically placed such indirect Anglo-Irish references in his play to portray his anti-colonial interests for the whole play can be interpreted in that light: Clov is an Irish descendant whose father had been kept at Cobh Harbor because of his political activities to be sent to Australia. He then rescues himself and is successful in finding a shelter to his little son Clov in home of Hamm , a powerful English Landlord who possesses a great deal of corns. By relying on Pearson's idea many things become clear about the relation between Hamm and Clov as the play will somehow find a historical basis according to which postcolonial studies can be performed. Clov represents then the poor Irish man who is fated to be a slave to his English master and it is internalized in him in a way that he cannot find an alternative.

The last thing to talk about here is the matter of Clov's language that is directly related to his identity. If Clov is considered to be Hamm's Irish slave, his language must be the focus of attention in this study as he "like all oppressed people, is a victim of the master because that foreign speech provides the structure in which he must think as well as speak" (Hyland \& Sammells, 1994, pp. 200-201). This can be again related to Spivak's notion of subaltern and his inability to express himself - discussed early in this study. Clov is by ethnicity an Irish man, but the act of Hamm's colonialization has forced him to use English, think like an English man and behave like English people. However, according to Frantz Fanon (1963), the colonized may finally revolt against all these repressions as he starts moving toward consciousness about his true living reality. These revolutionary acts first of all manifest themselves in the language of the colonized and as Bhabha (1990) has mentioned in case of mimicry and ambivalence, the colonized will finally express himself through the very medium that the colonizer has taught him. That is why the audience will soon find Clov saying to Hamm: "I use the words you taught me. If they don't mean anything anymore, teach me others, or let me be silent" (Endgame: 44). This is an allusion to the colonial contet of Caliban in The Tempest. But it is not the only revolutionary act of Clov as at the end the last phrase of his utterance will be fulfilled when Hamm faces nothing but silence in response to his calls at Clov's departure. In fact, by such an ending Beckett artistically reasserts what he had once portrayed in Waiting for Godot: It is an Irish endgame that would checkmate the idea of colonialization in any form and the futile labor of waiting without any action in hope of the change that may come by a savior of the colonized.

\section{Conclusion}

It was said that Ireland's dramatic history and its precedence has made it different from any other European tradition of drama - what has been put into analysis by many critics and has provided the material for many studies in case of literary criticism, dramaturgy as well as literary history. But what has given the present study a new dimension is its attempt to look at this issue from another prospect: the postcolonial study of Irish Drama. To do so, Samuel Beckett was taken as the representative dramatist and two of his plays Waiting for Godot and Endgame were explicated. What seems worth mentioning at the final point is the way these two plays lend themselves to a study of such quality, and the adaptability of the postcolonial theories to Beckett, his ideology and his worldview despite all the oddities and contradictions that may block the way at early steps. One must have it in mind the fact that the study of this literary and dramatic figure has become so much stock in the decades in result of the pre-assumptions based on the notions like absurdity, placenessness and universality. This outcome may give one the following hints:

- England's long dominance on Ireland in different prospects is very important and can be taken into consideration as one of the main factors affecting the literary and dramatic productions of this country. This fact may let Ireland be categorized under the title of Postcolonialism in hope of being studied based on postcolonial theories, but it shall be mentioned that it has its own complexities and is very different from what may be important in studying other so-called postcolonial countries like: India, Malaysia, Nigeria, etc. Any overgeneralization or any view of Ireland, its history and its people as stock or ready to embrace other postcolonial frames without any challenge is misleading.

- Studying Samuel Beckett and his works may assist much to the maturation or development of postcolonial theories as the emphasis of the theories of such kind is on what is local, contextual and ethnic before any universalizing based on general cosmopolitan ahistorical views. Focusing on what is Irish and its relation to this dramatist's worldview and the true historical point where he stands, gives more reliability or an authentic weight to the logic beyond a postcolonial study.

- Postcolonialism is to meet new horizons and can be more referable if its power in literary criticism is enhanced. This is only possible when it is innovatory and has something new to tell. It can be claimed that the same thing happens in what has been done here in case of Beckett: Other reading of Beckett's Waiting for Godot and Endgame have ceased to be comprehensive enough and cannot be much illuminating in dealing with things in detail. They just rely for example on Absurdism, Existential Philosophy, or the notion of Savior in void and are not able to connect them with each other. But the present study has been an attempt not only to connect them all, but also a struggle to provide a logical base for that by relying on Beckett's personal life, his worldview and its metamorphosis in accordance with his Irish -French transmission and the two different phases of his life that are the Pre-War and post-war Periods. 


\section{References}

Ashcroft, B., Griffiths, G. \& Tiffin, H. (2002). The Empire Writes Back: Theory and Practice in Postcolonial Literature. $2^{\text {nd }}$ ed. London: Routeledge, 2002.

Ashcroft, B., Griffiths, G. \& Tiffin, H. (1995). The post-colonial studies reader. London: Routledge,.

Bhabha. H. K. ( 1990). Nation and Narration. $1^{\text {st }}$ ed.London:Routledge.

Beckett, S. (1990). The Complete Dramatic Works of Samuel Beckett. London: Faber Faber.

Brandabur, C. (2006). "The Elephant in the Living-Room: A Postcolonial Reading of Waiting for Godot". Cross Culture ,85, 128-151.

Esslin, M. (2001). The Theatre of Absurd. $3^{\text {rd }}$ ed. New York: Vintage.

Fanon, F. (1963). The Wretched of the Earth, New York: Grove Weidenfeld.

Ghanbari, M.R. (2008). "A Comparative Study of the Notion of Waiting for a Savior in Religion and in Waiting for Godot". World Applied Sciences Journal 3: 733-737.

Gleitman, C. (2008). A Concise Companion to Contemporary British and Irish Drama. Oxford: John Willey \&Son, Ltd.

Grene, N. (2004). The politics of Irish Drama: Plays in Context from Boucicault to Friel. Cambridge: Cambridge University Press.

Hodges, S. (2010). The Digital Absurd. Unpublished Doctoral. Dissertation, the School of Literature, Communication and Culture: Georgia Institute of Technology.

Hyland, P. \& Sammells,N.( Ed.). ( 1994). Irish Writing: Exile and Subversion. London: Palgrave.

Kamyabi Mesak, A. ( 2002). Beckett's Last Interview. trans. Farideh Razi. Tehran: Arvij.

Knowlson, J. (2004) Damned to Fame: The Life of Samuel Beckett. New York: Grove Press.

McDonald, R. (2002) Tragedy and Irish Literature: Synge, O'Casey, Beckett. New York: Palgrave.

Morash,C. (2002). A History of Irish Theatre: 1601-2000.Cambridge: Cambridge University Press.

Pearson, N. C. (2001) " 'Outside of Here It's Death': Co-Dependency and the Ghost of Decolonization in Endgame". ELH 68, (1): 215-239.

Richards, S, (Ed.). (2004). The Cambridge Companion to Twentieth-Century Irish Drama Cambridge: Cambridge University Press. Uhlmann, A. Beckett and Poststructuralism. Cambridge: Cambridge University Press. 